\title{
Tomohon City Community Understanding of Tolerance
}

\author{
${ }^{1}$ Theodorus Pangalila* \\ Pancasila and Civic Education \\ Department \\ Universitas Negeri Manado \\ Tondano, Indonesia \\ theopangalila@unima.ac.id
}

\author{
2Jeane Mantiri \\ Public Administration Study Program \\ Universitas Negeri Manado \\ Tondano, Indonesia \\ jeanelitha@unima.ac.id
}

\author{
${ }^{3}$ Mardan Umar \\ Pancasila and Civic Education \\ Department \\ Universitas Negeri Manado \\ Tondano, Indonesia \\ mardanumar@unima.ac.id
}

\begin{abstract}
Indonesia is plural and multicultural nation. Plural because it consists of various backgrounds and multicultural because it has many cultures. The fact of the diversity of the Indonesian people is something to be proud of it. However, the current problem that threatens plural and multicultural nation unity is the development of radical ideas and intolerance movements. The main objective of this study is to uncover the perception of the people of Tomohon, North Sulawesi, about tolerance. This research is a type of qualitative research with descriptive data presentation. The data source in this study is the community and government in the city of Tomohon. Data collection through observation, interviews and documentation studies. This study found that the tolerance of the people of Tomohon was evident in their lives in public places such as markets, social activities, joyful activities and sad activities. The local wisdom of the community dramatically influences the community's perception of tolerance. This study recommends further research on efforts to maintain tolerance in the community.
\end{abstract}

Keywords: Understanding, Society, Tolerance

\section{INTRODUCTION}

An indisputable fact is that Indonesia is a vast country and an archipelagic country with abundant natural and cultural resources. Indonesia is known by the entire world as a country rich in diversity of ethnicities, races, cultures and religions. Indonesia stands firm and sharp as a big country because it is supported by such diversity. Indonesia unites such diversity with the symbol and also the identity of an Indonesian nation, Pancasila. "Pancasila as an identity that unites the Indonesian people with the motto" Unity in Diversity ", different but still one soul, this is a very extraordinary message from the nation's founders to their children and grandchildren as the nation's next-generation, they hope that even though Indonesia consists from many ethnic, cultural, religious and racial differences, but struggles" [1], [2]. The fact above clearly shows that Indonesia is plural and multicultural country. In the study of social science, pluralism is a terminology that contains the interaction of groups that are united because they have mutual respect, respect and even have a tolerant attitude with each other.
Indonesia is a country that has cultural diversity or is also multicultural. In multicultural societies, they have unique types/patterns of behaviour. Something that is considered very abnormal by certain cultures but is considered ordinary or mediocre by other cultures. Such differences often lead to contradictions or conflicts, disagreements and disinteractions in multicultural societies. The current era is a multicultural and plural era, where all people and all elements are required to be interdependent and bear the fate together for the sake of creating lasting peace. One crucial part of the consequences of a global life order marked by ethnic, cultural and religious pluralism, is to build and re-grow theology of pluralism in society [3].

Lately, there have been increasing cases of intolerance or incidents in Indonesia. Intolerance is a form of unpreparedness or inability to accept differences in views, beliefs and behaviour of others. As long as it has only limited to the level of attitudes and ideas, the intolerant view is something healthy. Because everyone tends to justify the beliefs that he has believed, however, intolerance will start to become a problem when translated into action. For example, several cases of intolerance in Indonesia can be seen from the data submitted by Imparsial that in 2019 there were 31 cases of intolerance or violations of freedom of religion and belief in Indonesia. Some 28 cases were carried out by residents who were mobilized by specific religious organizations or groups. There are 31 cases of intolerance or violations of religious freedom spread in the Indonesian province. The types vary, ranging from the prohibition of the establishment of places of worship, the prohibition of celebrations of ethnic culture, destruction of places of worship to the refusal to the neighbour to those of no religion. According to Imparsial data, the highest number of intolerant cases is the prohibition or dissolution of certain rituals, teachings, lectures, and religious services, which is 12 cases.

Furthermore, 11 cases of intolerance occurred in the form of a ban on the construction of houses or places of worship of a particular religion. While for the destruction of houses of worship there were 3 cases, bans on the 
celebration of ethnic culture, in this case, Cap Go Meh as many as 2 cases, arrangements for how to dress, appeals to certain religious sects, and the rejection of neighbours with no religion in each case. Furthermore, Setara Institute also revealed that several cases of intolerance occurred again in the last few days. Some parties strongly condemned religious violence because it was considered to tarnish diversity and hurt the face of democracy in the country. The Setara Institute considers this case of religious violence as a 'slap' for religious leaders and the government who recently held a Large Council of Religious Leaders for National Harmony in Jakarta on 8 to 10 February 2018. Some of the data on intolerance cases that have been collected by the Setara Institute are as follows: (1). Destruction of Temples in Lumajang, East Java, (2). Attack on the ulema in Lamongan, (3). Destruction of the mosque in Tuban, (4). Bomb threat at Kwan Tee Koen Karawang temple, (5). Attack of the Church of Santa Lidwina Sleman, (6). Persecution of Monks in Tangerang.

Events that show the attitudes of intolerance above certainly contradict the reality of Indonesia as plural and multicultural country and nation. According to reference [4], some of the main factors that enable ethnic conflict to surface or become open conflict are: First, the change in political constellation during the reform era and the climate of freedom which is upheld into fertile fields to express the unrest of several ethnic groups that have been part of the Indonesian nation. Second, the uneven development in various regions in Indonesia was realized or not, polarized based on ethnic groups. The struggle for resources that should be based on fair competition with universal criteria becomes a field of conflicting cultural values. At this point, as in colonial times, economic stratification overlaps with ethnic identity. There is no functional integration between various ethnic groups. Third, it is an undeniable fact that in Indonesian society, ethnic identity, in this case, ethnicity which includes cultural values and customs, is still an essential factor in community life, especially in rural areas [4].

Conflict phenomena that occur in Indonesia today indicate a lack of tolerance; both tolerance of other religions and of other cultures. Tolerance is essentially an attitude and action that respects differences in religion, ethnicity, ethnicity, opinions, attitudes, and actions of others who are different from him (4). Tolerance develops within the framework of diversity in various dimensions of life so that harmony and harmony in life can be realized, far from conflicts and social tensions, even more, conflicting and hostility between each other in society [5].

In contrast to what is happening in various regions in Indonesia which are engulfed by various horizontal conflicts, the harmony of the people of North Sulawesi is well maintained; its people remain calm, safe, and peaceful in harmony. North Sulawesi seems without problems, even though the residents of this province are also diverse in ethnicity, religion, race and language [6].

In a smaller context, the city of Tomohon as part of the Province of North Sulawesi also shows a harmonious and tolerant life. Tomohon city community varies from ethnicity, religion and language. Although the majority of the people are from the Minahasa tribe, some people come from other tribes such as Javanese, Sangir, Bolaang Mongondow, Gorontalo, Totemboan and Chinese. In terms of religion, the majority of the people of Tomohon are Christians, but there are also Muslims, Buddhists and Confucians.

The people of North Sulawesi, especially the people of Tomohon, live in harmony because of the strength of the local socio-cultural values (local wisdom) that are the glue of the people. The word local wisdom is used to indicate the existence of a concept that in local sociocultural life there is a nobleness, a height of values, truth, goodness and beauty that are valued by citizens so that it is used as a guide or guideline to build patterns of relationships between citizens or as a basis for building the life goals that they want to realize [7], [8]. The dominant socio-cultural values in the city of Tomohon are the culture of Si Tou Timou Tumou Tou, Mapalus and Torang Samua Basudara. Even in North Sulawesi, there is one institution that has a role in maintaining interreligious harmony, namely: BKSAUA (Interfaith Cooperation Agency). These two cultures in their development were combined to become the slogan of the people of North Sulawesi, Torang Samua Basudara (we are all brothers). This motto clearly illustrates how the people of North Sulawesi live in harmony, full of brotherhood.

From the above background, in this study, the researcher is interested in explicitly examining "Tomohon City Community Understanding of Tolerance." Based on the description and phenomena that have been found in the background above, the following research questions are formulated: (1). What is the form of tolerance of the people of Tomohon City? (2). What is Tomohon's understanding of tolerance?

\section{RESEARCH METHODS}

In this study, researchers chose to use a qualitative descriptive approach. Qualitative research is a method for exploring and understanding the meaning of several individuals or groups of people ascribed to social or humanitarian problems. This qualitative research process involves essential efforts, such as asking questions and procedures, collecting specific data from participants, analyzing data inductively starting from specific themes to general themes, and interpreting the meaning of data. This research was conducted in Tomohon City, North 
Sulawesi. The reason for choosing Tomohon as a research location is because Tomohon is famous as a city full of tolerance. The majority of the people of Tomohon are from the Minahasa tribe and are Christians, but in real life, they can live peacefully and side by side with immigrant communities, the majority of whom are from the island of Java and a variety of Muslims. The instrument used in collecting data to answer the problem of this research is to use a qualitative approach instrument as follows: (a). The main instrument is the researcher himself (key instrument) using analytical thinking techniques to be able to make/conclude/verification of the phenomenon under study. The key informants in this study are local government, religious leaders, interfaith harmony forum, traditional leaders, community leaders and local and migrant communities. (b). Assistive instruments are means or tools that can assist research (key instruments) in drawing conclusions or making verification of the phenomenon under study.

According to reference [9], data collection techniques are the most strategic step in research because the primary purpose of the research is to obtain data. Without knowing data collection techniques, the researcher will not get data that meets the established data standards. In this regard, the data collection techniques that will be used by researchers in this study are: Observation, Interview, Documentation, and literature study. In conducting data analysis, researchers will immediately process and analyze the data collected so that the data obtained does not accumulate. The purpose is to make it easier for researchers to analyze the data obtained after that. Following this is the data analysis step down (11). In testing the validity of the data, the researcher will use internal validity (credibility) in the aspect of truth value, in its application in terms of external validity (transferability), and reliability (dependability) in the aspect of consistency, and objectivity (confirmability) in the naturalist aspect (12). In qualitative research, the level of validity is more emphasized on the data obtained. The confidence of the research data can be said to have a significant influence on the success of a study.

\section{RESULT AND DISCUSSION}

\section{Norms that Apply in Society}

Relationships and interactions between one person and another group are the fundamental nature of individual life every day. In these social interactions, each individual plays their respective roles following their social status, position and role. Norms and values adhered to in society underlie human action amid social interaction. Norms that apply in society become the guide of every individual in damaging the needs and interests of his life without harming others, let alone breaking the rules that have been set. Thus a peaceful, orderly and orderly life can be realized. Humans in their lives in the midst of society are, in essence, always under the influence of religious practices, norms, politeness and decency and are also governed by the regulations that apply in society. The point here is that every individual is subject to social rules that have a binding nature even obeyed by its members wherever the rules and rules are applied.

In the context of the Tomohon city community, it cannot be separated from the moral values that apply to the Minahasa community in general. According to reference [10], the concept of moral values is the orientation of the Minahasa community and is revealed through social behaviour, namely: (1) Masigi-sigian (mutual respect for each other); (2) Masaali (service, especially children to parents); (3) Marukup (togetherness/solidarity); (4) Making peleng/Paumung (deliberation-consensus); (5) Mapalus (helping each other). In addition to cultural factors, another factor that also influences the mindset and pattern of action of Tomohon city residents towards migrant communities of different religions and ethnicities is the religion of the local population. This supports the theory of reference [11] about religion which says that in general religion explains the fact that the values possessed by almost all societies are not only as a unity of mixed values but are arranged in levels (hierarchy). Religion establishes the highest values in this hierarchy. Therefore, culture and religion are two essential things that very powerfully influence the mindset and behaviour patterns of the local people of Tomohon in building a tolerance for immigrants from different religions and ethnicities.

Based on the results of interviews, it was revealed that in the association of daily life between local communities and migrants, there was never anyone who offended religion and ethnicity. Never even in words. People here have a high spirit of mutual respect. So far, there have never been conflicts between religions and tribes here. There was a stabbing incident carried out by a trader from Gorontalo who was Muslim against a local Christian. Certain elements tried to be raised into SARA issues but to no avail. The people remain calm, and the perpetrators are prosecuted.

Therefore, in the context of the life of the Tomohon people, the moral values that apply are the same as the Indonesian people in general. So far there have not been events that are so prominent about the SARA issue, but if it does occur then moral sanctions in the form of exclusion from the community will undoubtedly apply to the perpetrators, and of course, legal norms will be applied in accordance with applicable regulations. The norms adhered to by each individual and society plays an important role and function in controlling the kinds of behaviour that develop in each society. Norms in the most basic sense are collections of rules that must be obeyed and followed by all members of a society in their respective social spheres. These norms are usually 
institutionalized and contained social sanctions that function as a deterrent to community members in carrying out deeds or actions that deviate from the procedures and customs that exist in their society. These collective rules are generally only verbal but are well understood by each member of the community and have a function and role in influencing the behavior of each individual in social interaction and social relations. Concrete examples of collective rules. For example: how to respect the arguments of others, how to respect parents and parents, rules for not cheating others, norms for healthy living, and norms in a shared life. The stronger the collective norms in a society, association, community or group, it will strengthen the lives of these people, especially in the face of the influence of globalization. Thus in social capital, norms that apply in a society are a supporting element in the formation of social cohesion that is continuously supported and strengthened by members of a community group. Communication with Language Media between

\section{Local Communities and Migrant Communities}

A language is a tool or tool used in conveying what we think to others. However, in a broad sense, also, language is a tool or means to interact or communicate with others. In interactions between people, language plays an important role. Tomohon city community is part of the Minahasa tribe, especially the Tombulu sub-ethnic group. But the Buttonu sub-ethnic group used daily interactions in the Tombulu language. However, in relation and interaction among the community in general, the Manado language and Indonesian language are often used too.

From interviews with several informants, it was revealed that in the communication and interaction between local people and migrants, the languages commonly used were Indonesian and Manado. Except for migrants who are fluent in Tombulu, then in interaction and communication with the local community, they will use the Tombulu language.

Furthermore, the behaviour of the community in their interactions with the local community usually enters through the tribe. The newcomers first got to know the culture, habits, ways to get along, words said, until polite coconut milk local communities in the city of Tomohon. This is in line with the symbolic interaction theory, where the most fundamental characteristic is the existence of a relationship between humans in society or the relationship between a society and its members that occur naturally. In this case, the symbols they created are a sign of interaction between them. Here a social reality is seen as a series of events experienced by a group of people in their society. In this process of interaction, individuals interact in a conscious state. Therefore, symbolic interactions are related to physical, vocal, bodily movements, and one is bodily expressions. All of them have meaning and purpose, and in this perspective are referred to as "symbols".

\section{CONCLUSION}

Based on the results of the study, it can be concluded that the people of Tomohon live in an atmosphere of tolerance because there are norms of life that originate from the local culture. Residents and migrant communities continue to maintain an atmosphere of tolerance amid differences in religion, ethnicity, language, and culture.

\section{ACKNOWLEDGMENT}

The author would like to acknowledge the Ministry of Higher Education, Science, Research and Innovation in providing the funding of this research project and to the Dean of Faculty of Social Science, Manado State University in supporting the publication of this article.

\section{REFERENCES}

[1] T. Pangalila, B. Ngarawula, and K. Sadhana, 'Tolerance behavior among society in city of Tomohon, North Sulawesi', Int. J. Humanit. Soc. Sci. Res., vol. 4, no. 4, pp. 46-49, 2018.

[2] J. Saputra, 'Pentingnya Pluralisme!', https://www.qureta.com/post/pentingnya-

pluralisme, 2017. [Online]. Available: https://www.qureta.com/post/pentingnyapluralisme.

[3] H. DM and M. Rijal, 'Pembinaaan Toleransi Antar Umat Beragama Perspektif Pendidikan Agama Islam Bagi Remaja Kota Kendari', AlIzzah J. Hasil-Hasil Penelit., vol. 13, no. 2, p. 224, 2018.

[4] P. Wirutomo, Sistem sosial Indonesia. Jakarta: Penerbit Universitas Indonesia, 2011.

[5] B. Endang, 'Mengembangkan sikap toleransi dan kebersamaan di kalangan siswa', J. Visi Ilmu Pendidik., vol. 1, no. 2, pp. 89-105, 2009.

[6] T. Pangalila and J. Mantiri, 'The role of Tomohon society's local wisdom in developing tolerance attitudes', Int. J. Eng. Adv. Technol., vol. 8, no. 5, pp. 366-372, May 2019.

[7] S. A. Kuntoro, 'Konsep Pendidik-an Berbasis Kearifan Lokal sebagai Dasar Pembentukan Karakter Bangsa', in Prosiding Seminar Nasional Ilmu Pendidikan, 2012. 
[8] R. Rukiyati and L. A. Purwastuti, 'Model Pendidikan Karakter Berbasis Kearifan Lokal Pada Sekolah Dasar Di Bantul Yogyakarta', J. Pendidik. Karakter, no. 1, pp. 130-142, 2016.

[9] Sugiyono, Metode Penelitian Kuantitatif Kualitatif $R \& D$. Bandung: ALFABETA,cv, 2011.

[10] J. Turang, Profil Kebudayaan Minahasa. Tomohon: Majelis Kebudayaan Minahasa, 1997.
[11] E. K. Nottingham, Agama dan Masyarakat: Suatu Pengantar Sosiologi Agama. Jakarta: Raja Grafindo Persada, 1994.

[12] I. B. Wirawan, Teori-Teori Sosial: Dalam Tiga Paradigma, Cet. Ke-3. Jakarta: Prenada Media Group, 2014. 